\title{
Suppression of sorbitol dependence in a strain bearing a mutation in the SRB1/PSA1/VIG9 gene encoding GDP-mannose pyrophosphorylase by PDE2 overexpression suggests a role for the Ras/cAMP signal-transduction pathway in the control of yeast cell-wall biogenesis
}

\author{
Gregory C. Tomlin, ${ }^{1}$ Grant E. Hamilton, ${ }^{2}+$ David C. J. Gardner, ${ }^{2}$ \\ Richard M. Walmsley, ${ }^{2}$ Lubomira I. Stateva ${ }^{2}$ and Stephen G. Oliver ${ }^{1}$
} Author for correspondence: Stephen G. Oliver. Tel: +44 161606 7260. Fax: +44 1616067360.
e-mail: steve.oliver@man.ac.uk

1 School of Biological Sciences, 2.205 Stopford Building, University of Manchester, Oxford Road, Manchester M13 9PT, UK

2 Department of Biomolecular Sciences, UMIST, PO Box 88, Manchester M60 1QD, UK

\begin{abstract}
Complementation studies and allele replacement in Saccharomyces cerevisiae revealed that PSA1/VIG9, an essential gene that encodes GDP-mannose pyrophosphorylase, is the wild-type SRB1 gene. Cloning and sequencing of the srb1-1 allele showed that it determines a single amino acid change from glycine to aspartic acid at residue 276 (srb 10276). Genetic evidence is presented showing that at least one further mutation is required for the sorbitol dependence of srb10276. A previously reported complementing gene, which this study has now identified as PDE2, is a multi-copy suppressor of sorbitol dependence and is not, as was previously suggested, the SRB1 gene. srb and pde2 mutants share a number of phenotypes, including lysis upon hypotonic shock and enhanced transformability. These data are consistent with the idea that the Ras/CAMP pathway might modulate cell-wall construction.
\end{abstract}

Keywords: SRB1/PSA1/VIG9/YDL055c, PDE2, cell-wall integrity, GDP-mannose

\section{INTRODUCTION}

The cell wall of Saccharomyces cerevisiae, a highly complex and dynamic structure, undergoes a number of modifications during different stages of the cell cycle, and also in response to environmental signals. The modifications to the wall must be tightly controlled. Understanding the coordinating factors and mechanisms that underlie cell growth and division is of major scientific and practical interest.

The yeast cell wall consists of almost equal amounts of $\beta$-glucans and mannoproteins. The third component, chitin, represents less than $1 \%$ of the total mass of the wall, but plays a highly significant role. A great number

\footnotetext{
†Present address: Millipore, BioProcess Division, Consett, Durham DH8 6SZ, UK.

Abbreviations: GPI, glycosyl-phosphatidyl-inositol; MAP, mitogenactivated protein; PKA, CAMP-dependent protein kinase; STRE, stressresponse element.
}

of genes have been shown to participate in cell-wall synthesis (see reviews by Klis, 1994; Cid et al., 1995).

Mannan is a complex of proteins modified by the addition of mannose-containing carbohydrate chains linked via $\mathrm{N}$ - and $\mathrm{O}$-glycosidic bonds, and in some cases, glycosyl-phosphatidyl-inositol (GPI)-anchors (reviews, Kukuruzinska et al., 1987; Herscovics \& Orlean, 1993; Orlean, 1997). The early steps in $\mathrm{N}$ glycosylation, which contributes about $90 \%$ of the mannan in the cell wall, are carried out by proteins encoded by essential genes, which indicates that there is a minimal level of $\mathrm{N}$-glycosylation required for cell viability. Most of the remaining mannan is in the form of O-glycosylated proteins (Tanner \& Lehle, 1987). Multiple O-glycosylation mutants can exhibit osmotic fragility, thereby indicating the importance of $\mathrm{O}$ glycosylation in maintaining the structural integrity of the cell wall (Gentzsch \& Tanner, 1996). The third form of glycosylation, that of addition of GPI anchors to proteins (for reviews see Cross, 1990; Englund, 1993), is essential for cell viability in S. cerevisiae (Leidich et al., 1995). All three modes of glycosylation require GDP- 
Table 1. Strains used in this study

\begin{tabular}{|c|c|c|}
\hline Strain & Genotype & Source/reference \\
\hline \multicolumn{3}{|l|}{ S. cerevisiae } \\
\hline YLG1 & MATa his 3 leu 2 ura 3 trp1 ade8 can1 & This report \\
\hline YLG2 & MAT $\alpha$ his 3 leu 2 ura 3 trp1 ade8 can1 & This report \\
\hline DJ12-9d & $\begin{array}{l}\text { MAT } \alpha \text { his } 3 \text { leu } 2 \text { ura } 3 \text { trp1 ade } 8 \text { can } 1 \\
\text { pde2::URA3 }\end{array}$ & M. Wigler* \\
\hline 4STLU & MATa srb1-1 srb trp1 leu2 ura3 & Stateva et al. (1991) \\
\hline 4SLUP & MATa srb1-1 srb trp1 leu2 ura3 pde2:: TRP1 & This report \\
\hline 7SLU & MAT $\alpha$ srb1-1 srb leu 2 ura3 & Stateva et al. (1991) \\
\hline 7SUP3 (7SUP6) & $M A T \alpha$ leu2 ura3 srb PSA1-LEU2 & This report \\
\hline YPH499 & MATa ura3 lys2 ade2 trp1 his3 leu2 & Sikorski \& Hieter (1989) \\
\hline BY4741 & MATa ura3 leu2 his3 met15 & Brachmann et al. (1998) \\
\hline $\mathrm{F} 7 \mathrm{a}$ & MATa ura3 his3 leu2 trp1 ade-mbp1::URA3 & $\begin{array}{l}\text { This report (spore from } \\
\text { CJ19 } \times \text { SJ } 21 R \text { ) }\end{array}$ \\
\hline G20b & $\begin{array}{l}\text { MATa ura3 lys } 2 \text { ade } 2 \text { trp1 his } 3 \text { leu } 2 \text { aad } 4:: U R A 3 \\
\text { PSA1-LEU2 }\end{array}$ & $\begin{array}{l}\text { This report (based on } \\
\text { YPH499) }\end{array}$ \\
\hline 20hPS1 & $\begin{array}{l}\text { MATa leu } 2 \text { ura } 3 \text { trp1 ade } 1 \text { his } 2 \text { psa1 ::TRP1 } \\
\text { pURA3/PSA1 }\end{array}$ & Benton et al. (1996) \\
\hline 20hPS1-2d & $\begin{array}{l}\text { MATa leu2 ura3 trp1 ade1 his } 2 \text { psa1:: TRP1 } \\
\text { pLEU } 2 / p s a 1^{\text {ts }}-2 d\end{array}$ & Benton et al. (1996) \\
\hline 20hPS1-3c & $\begin{array}{l}\text { MATa leu } 2 \text { ura } 3 \text { trp } 1 \text { ade } 1 \text { his } 2 \text { psa } 1:: \text { TRP1 } \\
\text { pLEU } 2 / p s a 1^{\text {ts }}-3 c\end{array}$ & Benton et al. (1996) \\
\hline BR15-3D & MATa his1 $\mathrm{Mal}^{-}$ & UMIST collection \\
\hline DC6 & MAT $\alpha$ leu2 his 4 & UMIST collection \\
\hline CJ19 & $\begin{array}{l}\text { MAT } \alpha \text { ura } 3 \text { ade } 2 \text { his } 3 \text { trp1 leu } 2 \text { met- } \\
\text { mbp } 1:: U R A 3\end{array}$ & L. Johnston $†$ \\
\hline SJ21R & MAT a ura3 leu 2 ade 1 & UMIST collection \\
\hline YPKC1L & MATa $p k c 1:: L E U 2$ ura3 trp1 leu2 & D. Levin $\neq$ \\
\hline DEY293-42c & $\begin{array}{l}\text { MAT a mpk1::TRP1 ura3 ade2-1 his3-11,15 leu2- } \\
\text { 3,112 lys2-95 ssd1-02 cgn1-100 }\end{array}$ & P. Sudbery $\$$ \\
\hline \multicolumn{3}{|l|}{ E. coli } \\
\hline JM109 & $\begin{array}{l}\mathrm{F}^{\prime} \text { traD36 } \text { lacl }^{\mathrm{a}} \Delta(\text { lacZ }) \text { M15 pro } A^{+} B^{+} / \\
\text {e14- }\left(\mathrm{McrA}^{-}\right) \Delta\left(\text { lac-proAB) thi gyrA96 }\left(\mathrm{Nal}^{\mathrm{r}}\right)\right. \\
\text { endA1 hsdR17 }\left(\mathrm{r}_{\mathrm{K}}^{-} \mathrm{m}_{\mathrm{K}}^{+}\right) \text {relA1 supE44 recA1 }\end{array}$ & Yanisch-Perron et al. (1985) \\
\hline XL1-Blue & $\begin{array}{l}{\left[\mathrm{F}^{\prime} \text { proA } A^{+} B^{+} \text {lacl }{ }^{\mathrm{q}} \mathrm{Z} \Delta \mathrm{M} 15 \operatorname{Tn} 10\left(\text { tet }^{\mathrm{r}}\right) \text { recA1 endA1 }\right.} \\
\text { gyrA96 }\left(\mathrm{Nal}^{\mathrm{r}}\right) \text { thi-1 hsdR17 }\left(\mathrm{r}_{\mathrm{K}}^{-} \mathrm{m}_{\mathrm{K}}^{+}\right) \text {supE44 relA1 } \\
\text { lac }\end{array}$ & Bullock et al. (1987) \\
\hline
\end{tabular}

* Cold Spring Harbor Laboratory, New York, USA.

† Medical Research Council, Mill Hill, London, UK.

$\ddagger$ Johns Hopkins University, Baltimore, MD, USA.

\$Sheffield University, Sheffield, UK.

mannose, either directly or indirectly. This is produced by the enzyme GDP-mannose pyrophosphorylase which is encoded by the essential gene PSA1/VIG9 (Benton et al., 1996; Hashimoto et al., 1997). PSA1 is a cell-cycleregulated gene with peak expression occurring near START (Benton et al., 1996).

Pkc1p (Levin \& Bartlett-Heubusch, 1992; Paravicini et al., 1992) is responsible for the activation of a number of protein-kinase genes whose products function in a typical mitogen-activated protein (MAP) kinase (MAPK) signal-transduction pathway that is significant in maintaining cellular integrity (see Molina et al., 1998 for a review). The MAP kinases under Pkc1p control are the MAPK kinase kinase (MEKK), encoded by BCK1/SLK1 (Lee \& Levin, 1992; Costigan et al., 1992), the MAPK kinase (MEK), encoded by MKK1 and MKK2 (Irie et al., 1993) and MAPK, encoded by MPK1/SLT2 (Lee et al., 1993; Mazzoni et al., 1993). Disruption of PKC1 results in sorbitol dependency, whilst disruption of the other members of the cascade causes temperature sensitivity that is rescuable by an osmotic stabilizer.

Normal cellular growth and cell-wall synthesis depend on the availability of nutrients. The Ras/cAMP signal transduction pathway has been demonstrated to play a 
Table 2. Plasmids used in this study

\begin{tabular}{|c|c|c|}
\hline Plasmid & Details & Source/reference \\
\hline pUC19 & E. coli vector & Yanisch-Perron et al. (1985) \\
\hline YEp13 & $2 \mu-L E U 2$ shuttle vector & Broach et al. (1979) \\
\hline YCp50 & CEN-ARS-URA3 shuttle vector & Rose et al. (1987) \\
\hline pRS316 & CEN-ARS-URA3 shuttle vector & Sikorski \& Heiter (1989) \\
\hline pRS425 & $2 \mu-L E U 2$ shuttle vector & Christianson et al. (1992) \\
\hline pRS426 & $2 \mu-U R A 3$ shuttle vector & Christianson et al. (1992) \\
\hline pSRB1-2 & $\begin{array}{l}14 \cdot 5 \text { kb chromosome IV fragment in YCp } 50 \text {, } \\
\text { complements srb1-1 }\end{array}$ & This study \\
\hline pSRB1-3 & pSRB1-2 with SalI fragment removed & This study \\
\hline pSRB1-4 & pSRB1-2 with ClaI fragment removed & This study \\
\hline pSRB1-5 & pSRB1-2 with HindIII fragment removed & This study \\
\hline pSRB1-9b & $\begin{array}{l}\text { ClaI-Bam HI fragment of pSRB1-2 in pRS316, } \\
\text { contains PSA1 }\end{array}$ & This study \\
\hline pSRB1-9c & $\begin{array}{l}\text { pSRB1-9b with BamHI-EcoRV fragment } \\
\text { removed }\end{array}$ & This study \\
\hline pSRB1-9d & $\begin{array}{l}\text { pSRB1-9c with LEU2 in Nsil-NheI sites and } \\
\text { is } u r a 3 \Delta\end{array}$ & This study \\
\hline pSRB1-10c & $\begin{array}{l}\text { Bam HI-ClaI fragment of pSRB1-2 in pRS426, } \\
\text { contains PSA1 }\end{array}$ & This study \\
\hline$p s a 1^{\text {ts }}-2 \mathrm{~d}$ & $\begin{array}{l}\text { ARS-CEN, LEU2 plasmid, temperature- } \\
\text { sensitive } p s a 1 \text { allele }\end{array}$ & Benton et al. (1996) \\
\hline$p s a 1^{\mathrm{ts}}-3 \mathrm{c}$ & $\begin{array}{l}\text { ARS-CEN, LEU2 plasmid, temperature- } \\
\text { sensitive } p \text { sa } 1 \text { allele }\end{array}$ & Benton et al. (1996) \\
\hline pSP1 & $\begin{array}{l}\text { psa1 from 7SLU PCR amplified and cloned in } \\
\text { pUC19 }\end{array}$ & This study \\
\hline pSP2 & $\begin{array}{l}\text { psa1 from 7SLU PCR amplified and cloned in } \\
\text { pUC19 }\end{array}$ & This study \\
\hline YEp95-PKC1 & $\begin{array}{l}\text { PKC1 on a } 4 \cdot 2 \mathrm{~kb} S p h \mathrm{I} \text { fragment in a } 2 \mu-U R A 3 \\
\text { shuttle vector }\end{array}$ & P. Sudbery* \\
\hline YEp352-BCK1-20 & $B C K 1-20$ on a $2 \mu-U R A 3$ shuttle vector & D. Levin $†$ \\
\hline YEp352-MKK1 & $M K K 1$ on a $2 \mu-U R A 3$ shuttle vector & D. Levin $†$ \\
\hline YEp352-MPK1 & MPK1 on a $2 \mu-U R A 3$ shuttle vector & D. Levin $†$ \\
\hline
\end{tabular}

*Sheffield University, Sheffield, UK.

† Johns Hopkins University, Baltimore, MD, USA.

major role in nutrient sensing, by regulating the activity of protein kinase A (for reviews see Broach \& Deschenes, 1990; Broach, 1991; Thevelein, 1994). An increase in cAMP levels causes activation of the cAMP-dependent protein kinase, PKA (Matsumoto et al., 1982; Toda et al., 1987a, b). This enzyme controls the phosphorylation of a number of different target proteins and, in this way, modulates their activity and function. There have been several reports which implicate a role for the Ras/cAMP pathway in the regulation of a number of cellular processes, such as cell-cycle progression (Baroni et al., 1994; Tokiwa et al., 1994), mating (Arkinstall et al., 1991) and pseudohyphal growth (Gimeno et al., 1992; Pan \& Heitman, 1999). The signalling is attenuated by the action of cAMP phosphodiesterase, encoded by PDE2, which degrades cAMP (Sass et al., 1986).

The mutation srb1-1, which confers hypotonic shock fragility to yeast cells (Venkov et al., 1974; Kozhina et al., 1979), has been an object of investigation. Work on strains carrying the srb1-1 mutation found a number of cell-wall changes, including alterations in glucan structure and composition (Blagoeva et al., 1991), and mannan content (Maerkisch et al., 1983). Investigations on the mode of action of actinomycin D (Waltschewa et al., 1976) and rifampicin (Venkov et al., 1975) have been facilitated by the hypersensitivity to antibiotics shown by strains carrying the srb1-1 mutation.

Initial efforts to identify the SRB1 gene resulted in the cloning of a complementing gene (Stateva et al., 1991), which was then reported to be the SRB1 gene. This gene, which we have now identified as PDE2, is not the SRB1 gene but merely a multi-copy suppressor of sorbitol dependence. The wild-type SRB1 gene has now been isolated and shown to be identical to the previously described gene PSA1/VIG9 (Benton et al., 1996; Hashimoto et al., 1997) which encodes GDP-mannose pyrophosphorylase. In addition, we present evidence that sorbitol dependency is a synthetic phenotype that 
involves at least one further mutant srb gene. The finding that PDE2 can rescue sorbitol dependence implicates the Ras/cAMP pathway in maintenance of cell-wall integrity. We have therefore carried out a number of phenotypic tests to seek further evidence to support this premise.

\section{METHODS}

Strains and media. Strains of Saccharomyces cerevisiae and Escherichia coli used in this study are listed in Table 1, together with relevant references and sources. The srb mutations were originally generated in S288C (Venkov et al., 1974).

Yeast media (YEPD, presporulation, sporulation, minimal and selective drop-out media with appropriate combinations of bases and amino acids) were prepared as described by Sherman et al. (1986) and Kaiser et al. (1994). Bacterial strains were grown in LB and LB + ampicillin prepared as described by Sambrook et al. (1989).

Plasmids, DNA preparation and manipulations. Plasmids employed in this study are shown in Table 2 and oligonucleotide primers in Table 3. Bacterial plasmid DNA was isolated using the alkaline lysis method of Birnboim \& Doly (1979). All DNA fragments used for subcloning were gel purified by the method of Heery et al. (1990). All enzymes (restriction endonucleases, T4 ligase, calf intestinal phos- phatase, Taq DNA polymerase and T4 DNA polymerase) were used according to the recommendations of the manufacturers.

Sequencing was carried out using an Applied Biosystems sequencer; see James et al. (1995) for a description of the method employed. The PCR-amplified srb1-1/psa1 DNA fragment from strain 7SLU was sequenced on both strands, using oligonucleotides psa1' $x$ ' (Table 3) to identify the mutation, as were the two $p s a 1^{\text {ts }}$ alleles. The $p s a 1^{\text {ts }}$ plasmids were recovered from strains 20hPS1-2d and 20hPS1-3c by the method of Ward (1990).

Colony PCR was used to check for correct integration of a DNA fragment after transformation into yeast. This was carried out as follows. A 1- or 2-d-old colony was picked and smeared on the inside of a PCR Eppendorf tube, microwaved on full power for $1 \mathrm{~min}$ and immediately cooled on ice. The yeast was resuspended in a mixture of all components necessary for PCR (except Taq) at the appropriate concentrations (Innis \& Gelfand, 1990), 5 U Taq DNA polymerase were added and 30 cycles of PCR carried out in a Perkin-Elmer Progene Thermal Cycler with an elongation step of 1 min per $\mathrm{kb}$ being used.

Transformation. E. coli strains were transformed either by the calcium chloride method as described by Sambrook et al. (1989) or electroporation with a Gene Pulser apparatus as recommended by the manufacturer (Bio-Rad). Sorbitol-dependent and $p d e 2$ disruptant yeast strains were transformed

Table 3. Oligonucleotide primers used in this report

Coordinates given for oligonucleotides psa1a to psa1j relate to GenBank accession no. U19608 (PSA1). See Fig. 1 for a schematic representation of the primers used in the replacement of srb1-1 by a PSA1-LEU2 cassette.

\begin{tabular}{|lll|}
\hline Name & \multicolumn{1}{c|}{ Sequence $\left(\mathbf{5}^{\prime} \mathbf{- 3}^{\prime}\right)$} & \multicolumn{1}{c|}{ Annealing position } \\
\hline psafor & AGCTCAGAGGTCACTATACG & 59 bp upstream of HindIII site in GenBank \\
& & U24437 (nt 538-557) \\
psarev & CGCGGATCCGCGAATACTA & 81 bp downstream of Nsi site in GenBank \\
& CAGACATTGATAGCC & U19608 (nt 2230-2209), Bam HI site in bold \\
psarev2 & CGATTCGCAATCACAAAC & First Cla I site downstream of PSA1, GenBank \\
& & U19608 (nt 3262-3245) \\
leuoli & TCGGCTGTGATTTCTTGAC & LEU2 ORF, 904 bp downstream of SpeI site, \\
& & GenBank U03498 (nt 5889-5907) \\
psaleu2 & ACTACACGGAAGTCAATCTCAC & $2 \cdot 61$ kb downstream of the first ClaI site \\
& & downstream of PSA1, GenBank Z74105 (nt \\
& & $4421-4442)$ \\
psa1a & AACAAAAACAGATGAGTG & $1901-1878$ \\
& ATATAG & \\
psa1b & GCCAATTTTTTGGTTGTC & $1498-1480$ \\
psa1c & TTTTCAACAAATCTGTCAATC & $1249-1229$ \\
psa1d & CAGAGAAAGTGATGTTA & $996-975$ \\
& ACACC & \\
psa1e & TCACCGATGGTGACATTAG & $1609-1591$ \\
psa1f & AGCACAAGACAAGCTACAAC & $712-731$ \\
psa1g & TTTGAAGAAGTACGAAAAGG & $950-969$ \\
psa1h & TAAATACGGTGTCATTGTCC & $1187-1206$ \\
psa1i & CAAAGGACTTCTTGTCTGG & $1429-1447$ \\
psa1j & ACCACTCCTTGGTCAAATC & $1660-1678$ \\
\hline
\end{tabular}




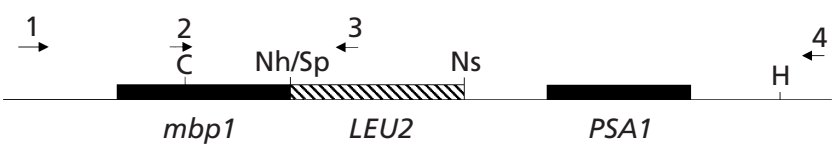

Fig. 1. Replacement of the srb1-1 allele by a PSA1-LEU2 cassette. Arrows show the directions and positions of the oligonucleotide primers. Primer 1 is psaleu2, primer 2 is psarev2, primer 3 is leuoli and primer 4 is psafor (Table 3 ). Primers 2 and 4 were used to amplify the replacement cassette from PSRB1-9d; primers 1 and 3 were used to confirm correct integration of the PCR product. The $3^{\prime}$ terminus of MBP1 is deleted in the gene replacement. C, Clal; $\mathrm{H}$, HindIII; Nh, Nhel; $\mathrm{Ns}, \mathrm{Nsil}$; Sp, Spel; the $\mathrm{Nh} / \mathrm{Sp}$ join results in a sequence that can not be recut by either enzyme.

by the no-lithium procedure of Philipova (1985) as described by Stateva et al. (1991). Other yeast strains were transformed by the method of Hill et al. (1991).

Genetic methods. Standard genetic techniques were used (Sherman et al., 1986; Kaiser et al., 1994) and the segregation of markers of interest followed by replica-plating yeast strains onto appropriate selective media. Sorbitol dependence was tested by comparing growth in media with and without $10 \%$ $(\mathrm{w} / \mathrm{v})$ sorbitol. The mating type of segregants was determined by crossing them with tester strains of both MATa (BR15-3D) and $M A T \alpha$ (DC6) types and selecting for the generation of prototrophic diploids.

Lysis tests. Hypotonic shock lysis tests were performed as described by Stateva et al. (1991). Lysis data were normalized as the number of $A_{260}$ units released per $\mathrm{OD}_{600}$ unit of pre-lysis cell suspension.

PCR amplification and cloning of psa1 in a srb1-1 strain. The srb1-1/psa1 allele was PCR amplified from strain 7SLU, using oligonucleotide primers psafor and psarev (Table 3). PCR amplification was carried out as described by Innis \& Gelfand (1990). The PCR product was digested with BamHI and HindIII to allow cloning into those sites in pUC19. This procedure was carried out twice, completely independently on each occasion.

PSA1 gene replacement. Strains 7SUP3 and 7SUP6 were generated by replacing the psa1 allele by a PSA1-LEU2 construct in strain 7SLU. This was made as follows: pSRB1$9 \mathrm{~b}$, which was constructed by ligating a BamHI-ClaI fragment containing PSA1 into pRS316, was digested with BamHI, the ends filled using T4 DNA polymerase, digested with EcoRV and religated. This plasmid, called pSRB1-9c, was constructed in order to remove the NsiI site in the pRS316 vector component.

The LEU2 gene was cut from YEp13 on a SpeI-NsiI fragment and ligated into the NheI and NsiI sites located downstream of PSA1 on pSRB1-9c. This plasmid, called pSRB1-9d, was then used as the template for the gene replacement.

The region of pSRB1-9d containing the PSA1-LEU2 construct was PCR amplified using psafor and psarev2 (Fig. 1). The PCR reaction mixture was digested with $P v u$ I to cut the pSRB1-9d template, thereby reducing the chance of false positives (i.e. colonies growing without leucine because they contain the plasmid, not the integrated construct). The PCR product was then transformed into 7SLU and transformants selected on minimal media containing sorbitol and uracil, but lacking leucine.
After colonies had developed, they were checked for correct integration of the construct. Oligonucleotides leuoli and psaleu2 (Fig. 1), which anneal to the LEU2 gene and outside the gene-replacement cassette respectively, were used to check for correct insertion of the PSA1-LEU2 cassette. Correct insertion of the cassette should give a $4.03 \mathrm{~kb}$ band, which was the case for 7SUP3 and 7SUP6.

\section{RESULTS}

\section{PDE2 is an extragenic suppressor of sorbitol dependence}

Stateva et al. (1991) isolated a $4.0 \mathrm{~kb} \mathrm{BamHI}$ fragment (YEp13::BamHI) that complemented the sorbitol dependence of strain 4STLU. However, two pieces of data cast doubt on this plasmid containing the SRB1 gene and led us to suspect that an extragenic suppressor may have been cloned. First, the cloned fragment was only capable of complementation when present on a multi-copy plasmid. Second, the disruption mutant (which was created using a $1.5 \mathrm{~kb}$ Pst I subfragment of the cloned gene) displayed a less severe phenotype than the original srb1-1 mutant. Although lysis occurred when subjected to hypotonic shock, the disruptant strain was capable of growth on media lacking an osmotic stabilizer, the key phenotype for which we have screened. Consequently, we sequenced this clone and identified PDE2 as the complementing gene. To demonstrate that PDE2 is a suppressor rather than the bona fide SRB1 gene, genetic analysis was performed on a diploid heterozygous for srb1-1 and homozygous for the loss of PDE2, disrupted by the insertion of URA3 on one allele and TRP1 on the other. The results of this genetic analysis (Table 4) show that PDE2 and SRB1 are not allelic. From this, we conclude that PDE2 is merely a multi-copy suppressor of sorbitol dependence, not the SRB1 gene itself, as previously reported (Stateva et al., 1991). In the light of these results, which demonstrate that the previously reported clone YEp13:: BamHI contains the PDE2 gene, the disruption strains constructed and described previously (Stateva et al., 1991) should now be referred to as pde2::TRP1 rather than srb1::TRP1. The 2:2 segregation pattern of sorbitol-dependent to sorbitolindependent colonies in the tetrad analysis also led us to believe that the srb1-1 mutation is the only one causing sorbitol dependence in srb strains. However, subsequent work revealed the situation to be more complex.

\section{Identification of PSA1 as the bona fide SRB1 gene}

In another attempt to isolate the SRB1 gene, we transformed a srb1-1 mutant (7SLU; Table 1) with a YCp50-based genomic library (Rose et al., 1987). Selection was carried out on the basis of growth without an osmotic stabilizer in the medium. Analysis of plasmids recovered through this procedure showed that they contained a $14.5 \mathrm{~kb}$ insert. Subcloning and sequence analysis, described by Gardner et al. (1996), identified several ORFs in the insert. Different subclones were constructed and transformed into 7SLU to identify the gene complementing sorbitol dependence. The maps of 
Table 4. Segregation pattern from the analysis of 48 four-spored tetrads of a cross between strains DJ12-9d and 4SLUP

URA3 was used for disruption of PDE2 in strain DJ12-9d and TRP1 was used for disruption of PDE2 in strain 4SLUP.

\begin{tabular}{|lcccccc|}
\hline Tetrad type & \multicolumn{5}{c|}{ Genotype } \\
\cline { 2 - 7 } & srb/URA3 & srb/TRP1 & $\begin{array}{r}\text { TRP1/ } \\
\text { URA3 }\end{array}$ & $\begin{array}{r}\text { MAT/ } \\
\text { URA3 }\end{array}$ & $\begin{array}{r}\text { MAT/ } \\
\text { TRP1 }\end{array}$ & MAT/srb \\
\hline Parental ditype & 4 & 4 & 47 & 11 & 11 & 9 \\
Non-parental ditype & 7 & 8 & 0 & 8 & 9 & 9 \\
Tetratype & 37 & 36 & 1 & 29 & 28 & 30 \\
Total & 48 & 48 & 48 & 48 & 48 & 48 \\
\hline
\end{tabular}

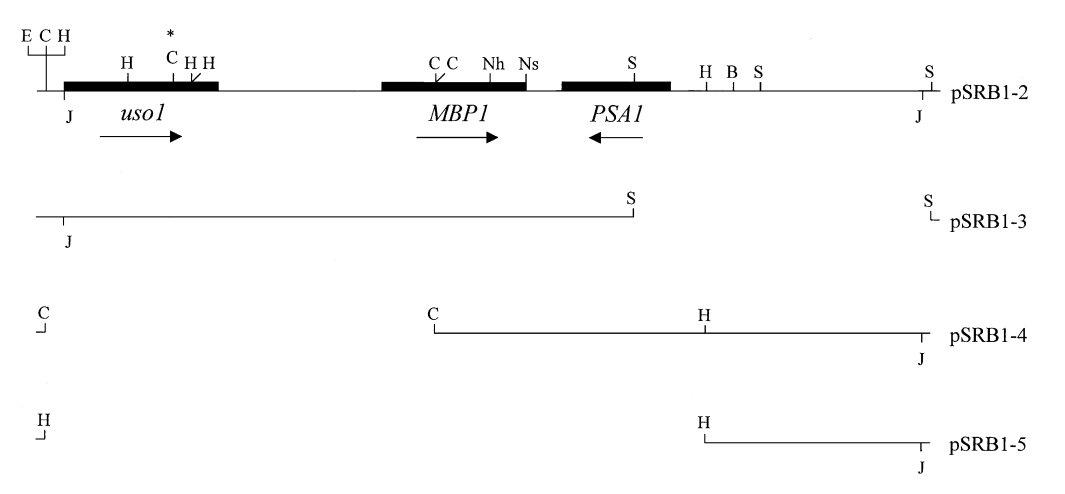

C

\begin{abstract}
Fig. 2. Subcloning of pSRB1-2, which complements sorbitol dependence. Only constructs that contain the entirety of PSA1 (pSRB1-2, pSRB1-4 and pSRB1-9b) are able to complement sorbitol dependence. The plasmid name is on the right side of the figure. The chromosomal centromere lies to the right of the figure. Arrows show the direction of gene transcription. YCp50 is the vector for each construct, except pSRB1-9b for which it is pRS316. B, BamHI; C, Clal; E, EcoRI; H, HindIII; Nh, Nhel; Ns, Nsil; S, Sall; J, Sau3Al/BamHI join between insert and vector; *, site not cut by restriction enzyme.
\end{abstract}

the constructs and the results of the complementation analyses are shown in Fig. 2. They indicate that, of all the genes present on the originally cloned insert, the sequences corresponding to the PSA1 gene (Benton et al., 1996) alone were capable of functional complementation of sorbitol dependence. The following experiments were carried out in an attempt to show whether SRB1 and PSA1 define the same gene.

First we tested the temperature sensitivity (at $37^{\circ} \mathrm{C}$ ) of strains bearing $p s a 1^{\text {ts }}$ mutant alleles, isolated and described by Benton et al. (1996), and kindly provided by the authors. We found that these mutants can be complemented by the addition of $1 \mathrm{M}$ sorbitol, a feature which had not been described previously. Therefore, it would appear that if SRB1 and PSA1 define the same gene, then srb1-1 and $p s a 1^{\text {ts }}$ mutants should differ in their dependence upon osmotic stabilizers for growth at $30{ }^{\circ} \mathrm{C}$, but share the phenotype of sorbitol dependence at $37^{\circ} \mathrm{C}$. Two of the $p s a 1^{\mathrm{ts}}$ alleles (designated $p s a 1^{\mathrm{ts}}-2 \mathrm{~d}$ and $p s a 1^{\text {ts }}-3 c$ ) were recovered and transformed into the srb1-1 mutant, 7SLU. These transformants were then tested for sorbitol dependence at $30^{\circ} \mathrm{C}$ and $37^{\circ} \mathrm{C}$. Strain 7SLU, carrying PSA1 on a single-copy plasmid (pSRB1$9 \mathrm{~b}$ ), and the $p s a 1^{\mathrm{ts}}$ mutants in a psa1s strain (Table 1 ) were also included for comparison. The $p s a 1^{\text {ts }}$ alleles successfully restored growth in 7SLU without sorbitol at $30^{\circ} \mathrm{C}$, but failed to do so at $37^{\circ} \mathrm{C}$, just as was observed with the $p s a 1 \Delta$ strains bearing the $p s a 1^{\text {ts }}$ mutant alleles. However, when 7SLU was transformed with the wildtype PSA1 allele, growth without sorbitol was restored at both $30^{\circ} \mathrm{C}$ and $37^{\circ} \mathrm{C}$. As the $p s a 1^{\text {ts }}$ alleles conferred the same phenotype on both 7SLU and the psa1 null mutant, this finding is consistent with the hypothesis that $s r b 1-1$ and $p s a 1^{\text {ts }}$ are alleles of the same gene.

A DNA fragment carrying the PSA1 gene with a LEU2 marker located beside it was used to replace the $p s a 1$ gene in a srb1-1 strain (see Methods). Strain 7SUP3, generated in this way, was tested for its susceptibility to hypotonic shock stability when grown on complete or minimal media, with or without sorbitol, at $30^{\circ} \mathrm{C}$ and $37^{\circ} \mathrm{C}$ (Fig. 3). Replacing one allele with another at the same locus is the best strategy to avoid misleading results due to variations in expression or gene dosage. Therefore, the finding that replacement of the mutant allele by a wild-type allele of the PSA1 gene simultaneously enabled growth to occur without sorbitol on both complete and minimal media at $30^{\circ} \mathrm{C}$ and $37^{\circ} \mathrm{C}$ demonstrates that PSA1 is not merely a suppressor of srb1-1, but actually represents the wild-type allele of the gene. 

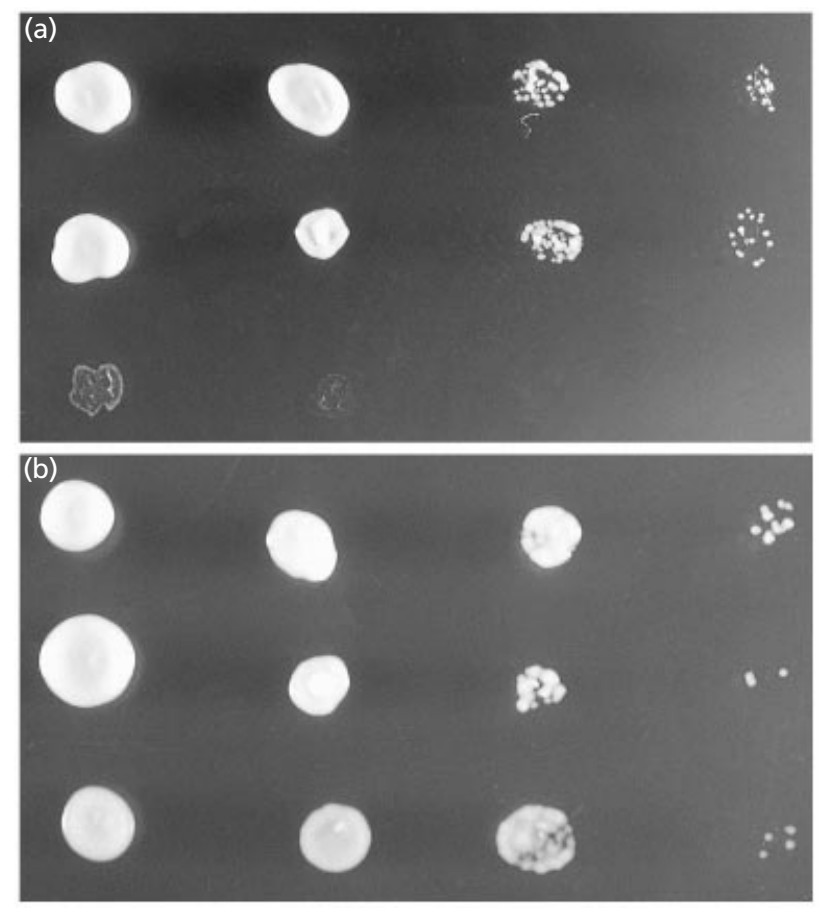

Fig. 3. Integration of a PSA1-LEU2 cassette into a $s r b 1^{\mathrm{D} 276}$ strain (7SLU) restores the ability to grow without sorbitol. (a) Growth without sorbitol, (b) growth with sorbitol. For both parts, growth was on YEPD agar at $30^{\circ} \mathrm{C}$, with a ten-fold serial dilution from left to right; top row 7SUP6, middle row 7SUP3, bottom row 7SLU.

\section{Identification of the mutations in the srb1-1 and psa $1^{\text {ts }}$ alleles of PSA1}

The psa1 allele in a srb1-1 mutant was PCR amplified and cloned (see Methods). Two independently produced clones, called pSP1 and pSP2, were sequenced on both strands of the DNA. The sequence revealed a single nucleotide change from a guanosine in the wild-type PSA1 at position 1588 (GenBank accession no. U19608) to an adenosine in the allele derived from a srb1-1 strain. In the amino acid sequence of the protein produced (Fig. 4), this causes a glycine at position 276 to be replaced by an aspartic acid. We sequenced this region of the PSA1 allele obtained from the gene library (on pSRB1-9b) using oligonucleotide psa1a and found that it matched the sequences in the database (GenBank accession nos U19608, U24437 and Z74103), most notably at the point where srb1-1 differs. The replacement in strain 7SLU of this mutant allele by a wild-type, thereby replacing this one nucleotide, enables growth to occur without sorbitol. This indicates that PSA1 is the wild-type SRB1 gene. Having identified the nature of the srb1-1 mutation, we shall henceforth refer to it as $s r b 1^{\mathrm{D} 276}$. Next, we sequenced, using the same oligonucleotides, the $p s a 1^{\text {ts }}$ alleles that had been generated by Benton et al. (1996) using mutagenic PCR. It is interesting that this revealed the presence of mutations in $p s a 1^{\text {ts }}-3 \mathrm{c}$ close to the site of the $s r b 1^{\mathrm{D} 276}$ mutation, indicating that this region may be of importance to the protein's function.

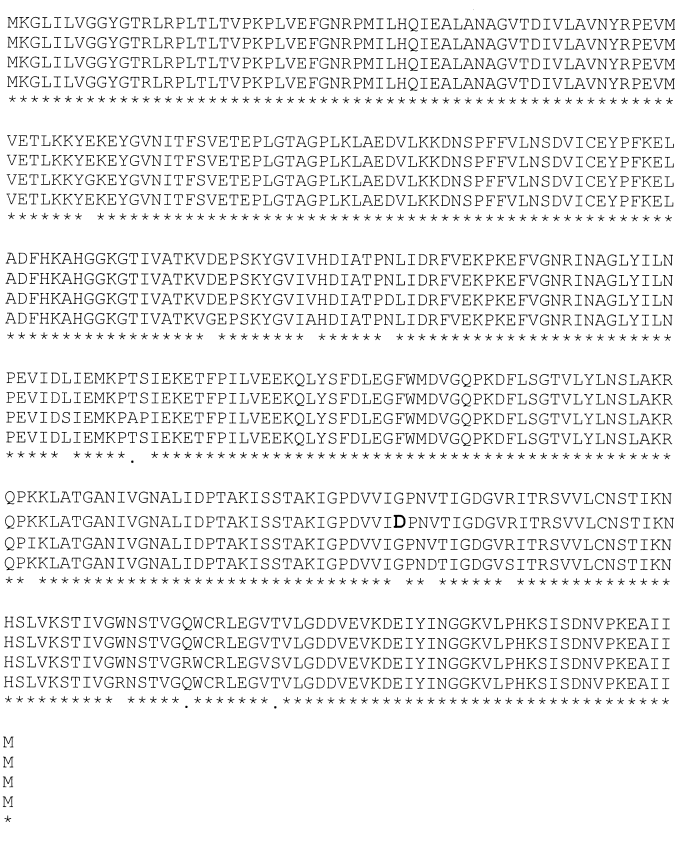

Fig. 4. Alignment of the amino acid sequences of the proteins specified by different PSA1 alleles. The top line is the wild-type sequence, the second is that of the srb1-1D276 mutant (the amino acid change is shown in bold), the third and fourth are the psa $1^{\text {ts }}$ alleles described by Benton et al. (1996). * indicates identical amino acids. indicates an amino acid changed to one of similar characteristics and a space indicates a change to an amino acid of different characteristics.

Table 5. Tetrad analysis data from a cross between 7SLU and $\mathrm{F} 7 \mathrm{a}$

The 22 tetrads that produced a segregation pattern of 3 sorbitol independent: 1 sorbitol dependent were not scored in the SRB1/MAT and MBP1/SRB1 comparisons, hence they give totals of 35 rather than 57. MAT is on chromosome III and MBP1 (which was marked by URA3) is adjacent to PSA1 on chromosome IV.

\begin{tabular}{|lccc|}
\hline Tetrad type & $\begin{array}{r}\text { MBP1/ } \\
\text { MAT }\end{array}$ & $\begin{array}{r}\text { SRB1/ } \\
\text { MAT }\end{array}$ & $\begin{array}{r}\text { MBP1/ } \\
\text { SRB1 }\end{array}$ \\
\hline Parental ditype & 9 & 7 & 33 \\
Non-parental ditype & 7 & 6 & 0 \\
Tetratype & 41 & 22 & 2 \\
Total & 57 & 35 & 35 \\
\hline
\end{tabular}

However, in $p s a 1^{\text {ts }}-2 \mathrm{~d}$, the mutations are away from this region, suggesting that there are other areas of functional importance in this protein.

\section{Tetrad analysis of a srb10276 mutant reveals the presence of at least one further mutant gene}

As well as the allele-replacement technique, we also used the more conventional technique of tetrad analysis to see if PSA1 is the wild-type SRB1 gene. However, when a 
Table 6. Tetrad analysis data from a cross between 7SLU (srb1-1/psa1 AAD4) and G20b (PSA1-LEU2 aad4::URA3)

$A A D 4$ is located close to the telomere of the left arm of chromosome IV (Delneri et al., 1999), SRB1/PSA1 is marked by a LEU2 gene. Of the 52 tetrads analysed, 37 showed 2:2 segregation of sorbitol independence: dependence, 13 were $3: 1$ and 2 were $4: 0$, hence only 37 of the srb1-1/PSA1-LEU2 tetrads could be classified. Only tetrads where both $U R A 3 /$ ura3 and LEU2/leu2 segregated in a 2:2 manner were used for this analysis.

\begin{tabular}{|lcc|}
\hline Tetrad type & $\begin{array}{c}\text { PSA1-LEU2/ } \\
\text { A AD4 }\end{array}$ & $\begin{array}{c}\text { srb1-1/ } \\
\text { PSA1-LEU2 }\end{array}$ \\
\hline Parental ditype & 10 & 37 \\
Non-parental ditype & 11 & \\
Tetratype & 31 & 37 \\
Total & 52 & \\
\hline
\end{tabular}

tetrad analysis of a cross between 7SLU and F7a (a wildtype strain) was conducted, only $38.6 \%$ of the spores were sorbitol dependent, as 22 of the 57 tetrads yielded more than two sorbitol-dependent colonies (Table 5). Since this is in contrast to our previous tetrad analysis result, in which sorbitol dependence to independence segregated 2:2 (Table 4), the analysis was repeated. This time however, strain 7SLU was crossed to YPH499PS, a wild-type yeast strain with a LEU2 allele integrated beside the PSA1 gene so that the segregation of PSA1 could be easily followed. Table 6 shows that, again, $3: 1$ and 4:0 segregation of sorbitol independence to dependence was observed. The ability to follow the segregation pattern of PSA1 allowed us to see that many $s r b 1^{\mathrm{D} 276}$ allele-bearing colonies were not sorbitol dependent.

Taking this information together, we had to produce a new explanation for what was occurring. For reasons we outline in the Discussion, we believe that there is at least one further mutant $s r b$ gene in strain 7SLU that plays a role in determining sorbitol dependence.

To support our belief that there is more than one srb gene, a tetrad that yielded 3 sorbitol-independent and 1 sorbitol-dependent progeny from a 7SLU $\times$ YPH499 diploid was taken and the region of the PSA1 gene in which the $s r b 1^{\mathrm{D} 276}$ mutation is found was PCR amplified using primers psa1a and psa1i. When sequenced, using these same primers, it was found that the $s r b 1^{\mathrm{D} 276}$ mutant allele segregated $2: 2$ in these colonies with the wild-type PSA1 allele. Hence, as well as the sorbitoldependent colony containing a srb1 $1^{\mathrm{D} 276}$ allele, one of the sorbitol-independent colonies also contained this allele. This demonstrates that the $s r b 1^{\mathrm{D} 276}$ gene is not the only one responsible for sorbitol dependence in strain 7SLU. The fact that $s r b 1^{\mathrm{D} 276}$ does play a role in sorbitol dependence in 7SLU cannot be disputed, given the evidence above (particularly the finding that replacement of the $s r b 1^{\mathrm{D} 276}$ allele in 7SLU by a wild-type PSA1 allele restores the ability of the strain to grow without
Table 7. Lysis test results

The $A_{260}$ is an indication of the amount of nucleic acid released upon hypotonic shock. Thus higher values indicate greater lysis. Values are the mean of two tests.

\begin{tabular}{|lr|}
\hline Yeast strain (with relevant genotype) & $\boldsymbol{A}_{\mathbf{2 6 0}}$ \\
\hline 4SLUP (isogenic to 4STLU, srb pde2) & $12 \cdot 0$ \\
7SLU (srb) & $9 \cdot 6$ \\
7SUP3 (isogenic to 7SLU, srb PSA1) & $8 \cdot 4$ \\
4STLU (srb) & $7 \cdot 5$ \\
DJ12-9d (pde2) & $3 \cdot 5$ \\
F7a (wild-type strain) & $1 \cdot 8$ \\
YLG1 (isogenic to DJ12-9d, wild-type) & $1 \cdot 0$ \\
YPH499 (wild-type strain) & $0 \cdot 9$ \\
\hline
\end{tabular}

sorbitol). To confirm this finding, we repeated this test with a tetrad generated from a cross of BY4741 (an S288C-derived wild-type strain) with 7SLU and obtained an identical result.

The question of the initial tetrad analysis (Table 4), which did give 2:2 segregation of sorbitol-dependent to -independent colonies, also had to be addressed. For reasons explained in the Discussion, we believe the homozygous $p d e 2$ background essentially masks the presence of additional $s r b$ gene(s) in the tetrad analysis in Table 4. Thus an additional analysis was conducted using a cross between YLG2 and 4STLU, which are isogenic to strains DJ12-9d and 4SLUP, but are wildtype for PDE2. Analysis of the tetrads from this cross again revealed $3: 1$ and $4: 0$, in addition to $2: 2$, sorbitolindependent to -dependent segregants, thus supporting our hypothesis [out of 33 tetrads (132 spores), 49 spores $(37 \%)$ produced sorbitol-dependent colonies, a value consistent with the other tetrad dissections].

\section{Hypotonic shock fragility and the Ras/cAMP dependent pathway}

PDE2/SRA5, the gene encoding the yeast high-affinity cAMP phosphodiesterase, has been disrupted previously with a modest increase in the concentration of intracellular cAMP being reported (Sass et al., 1986; Wilson \& Tatchell, 1988). However, under most conditions, pde 2 mutants have a nearly wild-type phenotype. As it has been demonstrated that there is more than one srb gene, where traits associated with the presence of $s r b 1^{\mathrm{D} 276}$ plus the other srb gene(s) are being referred to, we prefer the designation 'srb' (without a number). Since PDE2 has been found to be a multi-copy suppressor of sorbitol dependence in 4STLU, it was of interest to see if $p d e 2$ disruptants have similar phenotypes to those conferred by the srb genes.

Table 7 gives the results of lysis tests performed with strains of different genotypes. The $s r b$ and $p d e 2$ mutant strains had similar lysis levels; however, the srb pde2 double mutant shows a substantially increased lysis ability. Comparison of the isogenic pair 7SLU and 
Table 8. Transformation frequencies using the no-lithium method

Results are the mean of two experiments. YEp13 was used throughout, except for strains 7SLU and 7SUP3 where pRS425 was used.

\begin{tabular}{|lc|}
\hline Strain (with relevant genotype) & $\begin{array}{c}\text { No. transformants } \\
(\boldsymbol{\mu g} \text { DNA })^{-1}\end{array}$ \\
\hline 4STLU (srb) & $3 \cdot 7 \times 10^{3}$ \\
4SLUP (isogenic to 4STLU, srb pde2) & $3.6 \times 10^{3}$ \\
7SLU (srb) & $6 \cdot 1 \times 10^{2}$ \\
DJ12-9d (pde2) & $3 \cdot 1 \times 10^{2}$ \\
7SUP3 (isogenic to 7SLU, srb PSA1) & 85 \\
YLG1 (isogenic to DJ12-9d, wild-type) & 9 \\
\hline
\end{tabular}

7SUP3 (where 7SUP3 carries a wild-type PSA1 gene) reveals that, although 7SUP3 has a reduced lysis ability, this is still much higher than that of wild-type strains YLG1 and YPH499. This is consistent with the premise that there is more than one srb gene. Disruption of $p d e 2$ in strain DJ12-9d shows that it, too, has an increase in lysis ability compared to its isogenic wild-type partner, YLG1. Thus lysis ability can be regarded as a trait shared by $p d e 2$ disruptants and $s r b$ family genes.

Intact cells carrying srb mutations can be transformed by a modification of the procedure described by Ito $e t a l$. (1983), which does not require the use of lithium ions (Philipova, 1985; Stateva et al., 1991). We transformed several strains using this procedure. The results (Table 8) show that, like srb mutants, $p d e 2$ disruptants were capable of transformation without the use of lithium ions. However, the srb pde2 mutant, 4SLUP, did not show any increased competence for transformation compared to an isogenic strain (4STLU) carrying just the $s r b$ mutations. Comparison of the isogenic strains 7SLU $\left(s r b 1^{\mathrm{D} 276} s r b\right)$ and 7SUP3 (PSA1 srb) reveal that replacement of the $s r b 1^{\mathrm{D} 276}$ allele results in a ten-fold drop in the transformation frequency, however this is still ten times that of a wild-type strain, YLG1. This, too, supports the finding that there is more than one srb gene.

\section{Interaction with the PKC1 pathway}

As the $s r b$ mutations cause phenotypes similar to those caused by mutations in components of the PKC1 MAPkinase cascade, we investigated whether it was possible for overexpression of members of the cascade to rescue the sorbitol-dependence phenotype. Transformation of the srb strain 7SLU with one of either PKC1, BCK1-20 (a hyper-activated allele of the $B C K 1$ gene), MKK1 or $M P K 1$ on a multi-copy plasmid failed to rescue the sorbitol-dependency phenotype. PKC1 was also tested to see if it could suppress the temperature sensitivity of the $p s a 1^{\text {ts }}$ alleles, but was found to be unable to do so. Transformation of $p k c 1$ (YPKC1L) and $m p k 1$ (DEY29342c) mutant strains with PSA1 on a multi-copy plasmid was also incapable of rescuing the sorbitol dependence and temperature-sensitivity phenotypes.

\section{DISCUSSION}

\section{PSA1/VIG9, encoding GDP-mannose pyrophosphorylase, is the bona fide SRB1 gene}

The srb mutants were originally isolated on the basis of their sorbitol-dependent phenotype (Venkov et al., 1974). Additional phenotypes include the ability to lyse upon hypotonic shock, antibiotic hypersensitivity and increased permeability of the cell wall and membrane due to defects in their structure and composition (Maerkisch et al., 1983; Blagoeva et al., 1991; Kopecka et al., 1991). In a previous study (Stateva et al., 1991), a yeast chromosomal gene was isolated that complemented sorbitol dependence in a number of srb strains, including 4STLU. We have now identified this gene as PDE2 and further study has shown it to be a multi-copy suppressor of sorbitol dependence not, as previously reported, the SRB1 gene. Tetrad analysis clearly demonstrates this point (Table 4). This suppressor activity of PDE2 and the phenotypes indicative of compromised cell-wall integrity displayed by $p d e 2$ mutants, provide evidence that the Ras/cAMP signaltransduction pathway plays a role in maintaining the structural integrity of the yeast cell wall. Such a function for the Ras/cAMP pathway in both yeasts and filamentous fungi has been suggested previously (Trevillyan \& Pall, 1979; Baroni et al., 1994; Tokiwa et al., 1994).

In the attempt to clone the bona fide SRB1 gene described in this paper, we isolated the gene PSA1/VIG9 (Benton et al., 1996; Hashimoto et al., 1997). This gene complements the $s r b 1^{\mathrm{D} 276}$ mutation when transformed into yeast on a single-copy plasmid. The temperature sensitivity at $37^{\circ} \mathrm{C}$ of $p s a 1^{\text {ts }}$ alleles was rescued by sorbitol, and $p s a 1^{\text {ts }}$ alleles confer the same phenotype on both $\operatorname{srb} 1^{\mathrm{D} 276}$ and $p s a 1 \Delta$ mutants when carried on the same centromeric plasmid. Replacement of PSA1 in a $s r b 1^{\mathrm{D} 276}$ strain results in a sorbitol-independent phenotype (Fig. 3). Isolation and sequencing of the PSA1 gene from a $\operatorname{srb} 1^{\mathrm{D} 276}$ strain revealed the presence of a single base pair change, resulting in a glycine being replaced by an aspartic acid (Fig. 4) in the gene product. These results allow us to conclude that PSA1 is the wild-type SRB1 gene.

SRB1/PSA1/VIG9 has already been described in a number of reports. Benton et al. (1996) identified it as a plasmid suppressor of alg1. Disruption of this gene is lethal; however, phenotypes associated with mutations in it include vanadate resistance, geneticin hypersensitivity (Hashimoto et al., 1997) and temperature sensitivity (Benton et al., 1996). As we have found the temperature-sensitive phenotype to be rescuable by the addition of sorbitol to the growth media, susceptibility to hypotonic shock can also be added to this list of phenotypes. J. Schultz and G. Sprague (personal communication and GenBank accession no. U24437) isolated 
PSA1 as a multicopy suppressor of a $d p m 1$ mutant. Both ALG1 (Albright \& Robbins, 1990) and DPM1 (Orlean et al., 1988) are essential genes involved in N-glycosylation (for reviews see Kukuruzinska et al., 1987; Herscovics \& Orlean, 1993; Orlean, 1997), and both use GDP-mannose as one of their substrates. DPM1 has also been found to function in the O-mannosylation and GPI-anchoring pathways (Orlean, 1990).

The process of O-glycosylation has been found to be particularly important to cell-wall integrity. It involves addition of up to five mannose residues, donated either directly or indirectly by GDP-mannose, to a serine or threonine in a protein. Genes in the seven-member PMT family are responsible for the addition of the first mannose. Disruption of different members of this family can cause, in some cases, sorbitol dependence and, in others, death (Gentzsch \& Tanner, 1996, 1997). Disruption of the addition of the second mannose causes a slow-growth phenotype (Lussier et al., 1997a), as well as resistance to killer toxin and hypersensitivity to calcofluor white; traits associated with cell-wall defects (Lussier et al., 1996, 1997b). N-glycosylation is also thought to play a role in maintaining cellular integrity, as manifested by the osmotic sensitivity of mnn9 disruptants, which are defective in 1,6- $\alpha$-mannose backbone construction (Yip et al., 1994). N-glycosylation mutants also exhibit a higher wall porosity, resulting in increased sensitivity to antibiotics such as neomycin and geneticin (Shimma et al., 1997). In this last study, PSA1 was cloned as a suppressor of the neomycin sensitivity of an alg1 mutant. Increased cell-wall porosity is consistent with our finding that srb mutants are transformable without the need for lithium (Table 8).

\section{Sorbitol dependence of srb1-1 fragile mutants is a synthetic phenotype}

Addressing the tetrad-analysis results, we suggest that the reason for the $3: 1$ and $4: 0$ segregation pattern in some tetrads is that sorbitol dependence is not dictated by $s r b 1^{\mathrm{D} 276}$ alone, but requires the presence of at least one further mutant srb gene. However, as the total number of colonies that were sorbitol dependent from the two analyses given in Tables 5 and 6 is approximately $40 \%$, i.e. between 25 and $50 \%$, we can conclude that $s r b 1^{\mathrm{D} 276}$ is linked to the other srb gene(s). The $2: 2$ segregation of sorbitol dependence to independence in our first tetrad analysis (Table 4) is, we suggest, due to it being conducted in a homozygous $p d e 2$ background. The lysis test is a simple gauge of the degree of osmotic fragility of yeast strains. It measures the quantity of nucleic acid released when a strain is subjected to hypotonic shock. The lysis-test data (Table 7) demonstrate that a $p d e 2$ disruptant exhibits increased lysis compared to a wild-type strain. The $s r b$ pde 2 strain 4SLUP shows very severe lysis, considerably worse than that of the isogenic equivalent 4STLU, which has a wildtype PDE2 gene. Thus pde2 disruption clearly affects cell-wall integrity and this is an additive effect with other mutations. We suggest that the $s r b 1^{\mathrm{D} 276}$ mutation on its own does not cause sufficient weakening of the cell wall to cause sorbitol dependence, but that it requires a further gene, which also plays a role in maintaining cellwall integrity, to be mutated or disrupted. Thus, in the first tetrad analysis (Table 4), srb1 $1^{\mathrm{D} 276}$ was always with a pde 2 disruptant regardless of how any other srb gene segregated. However, the other tetrad analyses were conducted in homozygous PDE2 backgrounds with, in each case, one of the parents being essentially wild-type in character. Hence, when segregation of the $s r b 1^{\mathrm{D} 276}$ gene away from the other srb gene(s) occurred, there were a number of $3: 1$ and 4:0 sorbitol-independent to sorbitol-dependent tetrads. In a separate study, a comparison of strain 7SUP3 (PSA1 srb) to BY4741 (an S288C derived wild-type strain) on calcofluor white media $\left(0.5 \mathrm{mg} \mathrm{l}^{-1}\right.$ in YEPD agar) and SDS media $(0.09 \%$ SDS in YEPD agar) found that 7SUP3 was considerably more sensitive than BY4741. As these are standard tests for cell-wall sensitivity (Ram et al., 1994; Lussier et al., 1997c), these findings indicate phenotypes that could be expected of additional mutant srb gene(s), and may subsequently be used in cloning experiments.

Our finding of shared phenotypes for $p d e 2$ disruptants and srb strains also supports the premise that the Ras/cAMP pathway plays a role in maintaining cellwall integrity. However, the lysis and transformation data (Tables 7 and 8) also demonstrate the complexity of the relationships involved. Whilst introduction of a wild-type PSA1 allele into strain 7SLU (to produce strain 7SUP3) rescues sorbitol dependence and greatly reduces transformability using the no-lithium method, lysis ability remains high. Disruption of PDE2 in strain YLG1 (to produce DJ12-9d) also increases both transformability and lysis ability without causing sorbitol dependence. Whilst a srb strain carrying a pde 2 disruption (strain 4SLUP), as would be expected, remains sorbitol dependent, and shows enhanced lysis ability compared to its isogenic partner 4STLU, there is no increase in transformability. Although sorbitol dependence, lysis ability and transformability are all cell-walldependent features, different elements of the cell wall are clearly of importance in determining the nature of each trait.

\section{A role for the Ras/cAMP signal-transduction pathway in the control of wall biogenesis}

A clear elucidation of the signal pathways involved in cellular integrity in the srb strains will require not only the identification of the other srb gene(s), but also a greater understanding of the Ras/cAMP and PKC1 signal cascades, as rescue of the strains may be due to the impact of cAMP depletion on srb gene(s) other than $S R B 1$, or a wide range of genes and cellular processes leading to the general effect of increased cell-wall rigidity. Our finding that members of the PKC1 MAP kinase cascade did not suppress sorbitol dependence implies that these genes do not regulate the srb family. However, it is known that the PKC1 MAP kinase cascade regulates the $S w i 4 / 6 \mathrm{p}$ transcription factor 
(Madden et al., 1997), which in turn acts on SCB (Swi4Swi6-dependent cell-cycle box) boxes (Dirick et al., 1992). Benton et al. (1996) reported near-consensus SCB boxes in the promoter region of PSA1/SRB1. This would suggest that PSA1 could be under the control of the PKC1 MAP kinase. Our failure to find any rescue of the sorbitol dependence of srb mutants may indicate that the regulatory distance is too great and the mechanism too complex to allow this to occur.

Our findings that overexpression of PDE2 rescues a sorbitol-dependent strain, and that disruption of $p d e 2$ causes lysis ability (Table 7) and transformability without lithium (Table 8), traits shared by the srb mutant strains which are known to have a fragile cell wall, allow us to conclude that the Ras/cAMP pathway plays a role in maintaining cellular integrity. The role of Ras/cAMP in nutrient sensing (Thevelein, 1994) and phenotypes related to $p d e 2$ disruption, such as heat shock and starvation sensitivity (Sass et al., 1986), have long been known. Links with cell-wall construction have become apparent in recent years. The pseudohyphal development that yeast undergoes in response to nitrogen starvation is regulated in part by the Ras/ cAMP pathway. Ras $2 p$ is able to signal either to the MAP kinase pheromone-response pathway, causing shmoo formation, or to protein kinase A, causing filamentation (Mosch et al., 1999). In the PKA pathway, it is the three PKA catalytic subunits that can either stimulate (TPK2) or inhibit (TPK1 and TPK3) pseudohyphal development (Pan \& Heitmann, 1999). Both MAP kinase and cAMP signals converge on the large promoter of FLO11 (Rupp et al., 1999).

In addition to a role in pseudohyphal formation, a function for the Ras/cAMP pathway in the osmotic stress response is becoming apparent. One known downstream target of the PKA pathway is the stressresponse element (STRE) promoter sequence (CCCCT) This site is important in the regulation of stress-related genes since it is a target of the HOG MAP-kinase cascade (Varela et al., 1995; Molina et al., 1998) and the transcription factors Msn2p and Msn4p (Schmitt \& McEntee, 1996; Martinez-Pastor et al., 1996) which increase transcription of genes that enable the cell to endure greater stress. In contrast, the PKA pathway is thought to negatively regulate genes bearing an STRE sequence (Varela et al., 1995; Thevelein \& de Winde, 1999; Sasaki et al., 2000), thereby reducing the cell's tolerance to stress, but also allowing more rapid growth. The GRE1 gene, which has an unknown function, was found to be induced by different stresses, including hyperosmotic conditions. As well as being under the control of the HOG pathway, it is also regulated negatively by PKA and positively by the transcription factors Msn2/4p (Garay-Arroyo \& Covarrubias, 1999). Norbeck \& Blomberg (2000) conducted an extensive analysis of genes that are transcriptionally regulated by PKA in response to hypertonic stress. Low PKA activity and high osmotolerance correlated with increased expression of stress-induced proteins such as Ctt1p (an oxidative-stress resistance protein). The promoters of all induced PKA-dependent genes had STRE sites. They also found that mutants with constitutively low PKA activity, as would be the case when PDE2 is overexpressed, caused an expression profile consistent with osmotically stressed cells, thereby making them more tolerant of this stress. Cells in stationary phase show increased resistance to almost all forms of stress (Werner-Washburne et al., 1993). This is consistent with our work; mid-exponential phase cells are used for the lysis test, as those in the stationary phase give lower lysis values (data not shown). Cells undergo an increase in heat-shock tolerance as they enter stationary phase (Parry et al., 1976; Elliott \& Futcher, 1993). As cells growing slowly or in stationary phase have low PKA activity (Thevelein, 1994), it is possible that overexpression of PDE2 may exert its influence by altering the cells expression profile to one that is more tolerant of stress. Research carried out thus far has linked the low PKA activity induced by osmotic stress to hyperosmotic conditions. In this study, we have found evidence that it also appears to rescue cells in hypotonic stress conditions.

Growth is integrated with division in the $G_{1}$ phase of the yeast cell cycle, therefore the synthesis of the cell-wall components should be tightly regulated with the cell cycle during bud enlargement. A cell-division-cycle pathway exists linking PKC1 to activation of CDC28 at START (Marini et al., 1996), thus providing a link between glucan synthesis and the cell cycle. PSA1 has a similar expression profile to that of CLN2 (Benton et al., 1996). As CLN2 is negatively regulated by PKA in order to delay START when cells are growing on rich media, thereby allowing a large cell to develop before budding commences (Baroni et al., 1994; Tokiwa et al., 1994), similar regulation of PSA1 could ensure that its peak expression is timed to coincide with the cell committing to budding.

As well as general effects on the cell, PKA activity may also more directly impact on cell-wall integrity. Mannosylphosphorylation involves the transfer of a mannose 1-phosphate residue from GDP-mannose to Nand O-linked oligosaccharides (Odani et al., 1996; Nakayama et al., 1998). Two genes involved in this process, MNN6 (Wang et al., 1997) and MNN4 (Odani et al., 1996), encode a mannosylphosphate transferase and its positive regulator, respectively. Odani et al. (1997) found that under conditions of osmotic stress and in late exponential/stationary phase, the level of mannosylphosphorylation increased. It was also found that the process of mannosylphosphorylation was negatively regulated by PKA, with overexpression of the Tpk1p subunit decreasing mannosylphosphorylation and overexpression of Pde1p (Nikawa et al., 1987) increasing it. In a strain carrying a srb1-1 mutation, it would be expected that GDP-mannose availability would be reduced. As overexpression of PDE2 could be expected to optimize mannosylphosphorylation of mannoproteins, this could be a factor in increasing cellwall rigidity of $s r b$ mutants to allow rescue of sorbitol dependency. 


\section{ACKNOWLEDGEMENTS}

The authors would like to thank Ben Benton and Fred Cross (Rockefeller University), Janet Schultz and George Sprague (University of Oregon), Peter Sudbery (Sheffield University), David Levin (Johns Hopkins University), Michael Wigler (Cold Spring Harbor), Thomas Christianson (Southern Illinois University) and Lee Johnston (MRC, Mill Hill) for strains and plasmids; Carolyn James and Anne Wynne (UMIST) for assistance with sequencing; and Pencho Venkov (Bulgarian Academy of Sciences, Sofia) and Nianshu Zhang (Manchester University) for advice and encouragement. This work was supported by BBSRC studentships to G. C.T. and G.E.H., a BBSRC grant to S.G.O. and grants from the Wellcome Trust to R.M.W. and L.I.S.

\section{REFERENCES}

Albright, C. F. \& Robbins, P. W. (1990). The sequence and transcript heterogeneity of the yeast gene $A L G 1$, an essential mannosyltransferase involved in $\mathrm{N}$-glycosylation. J Biol Chem 265, 7042-7049.

Arkinstall, S. J., Papasavvas, S. G. \& Payton, M. A. (1991). Yeast $\alpha-$ mating factor receptor-linked G-protein signal transduction suppresses Ras-dependent activity. FEBS Lett 284, 123-128.

Baroni, M. D., Monti, P. \& Alberghina, L. (1994). Repression of growth-regulated G1 cyclin expression by cyclic-AMP in budding yeast. Nature 371, 339-342.

Benton, B. K., Driscoll-Plump, S., Roos, J., Lennarz, W. \& Cross, F. (1996). Overexpression of Saccharomyces cerevisiae $G_{1}$ cyclins restores the viability of alg1 N-glycosylation mutants. Curr Genet 29, 106-113.

Birnboim, H. C. \& Doly, J. (1979). A rapid alkaline extraction procedure for screening recombinant plasmid DNA. Nucleic Acids Res 7, 1513-1523.

Blagoeva, J., Stoev, G. \& Venkov, P. V. (1991). Glucan structure in a fragile mutant of Saccharomyces cerevisiae. Yeast 7, 455-461.

Brachmann, C. B., Davies, A., Cost, G. J., Caputo, E., Li, J., Hieter, P. \& Boeke, J. D. (1998). Designer deletion strains derived from Saccharomyces cerevisiae S288C: a useful set of strains and plasmids for PCR-mediated gene disruption and other applications. Yeast 14, 115-132.

Broach, J. R. \& Deschenes, R. J. (1990). The function of RAS genes in Saccharomyces cerevisiae. Adv Cancer Res 54, 79-139.

Broach, J., Strathern, J. \& Hicks, J. (1979). Transformation in yeast: development of a hybrid cloning vector and isolation of the CAN1 gene. Gene 8, 121-133.

Broach, J. R. (1991). RAS genes in Saccharomyces cerevisiae: signal transduction in search of a pathway. Trends Genet 7, 28-33.

Bullock, W. O., Fernandez, J. M. \& Short, J. M. (1987). XL1-Blue: a high-efficiency plasmid transforming recA Escherichia coli strain with $\beta$-galactosidase selection. Biotechniques 5, 376-378.

Christianson, T. W., Sikorski, R. S., Dante, M., Shero, J. H. \& Hieter, P. (1992). Multifunctional yeast high-copy-number shuttle vectors. Gene 110, 119-122.

Cid, V. J., Duran, A., Delrey, F., Snyder, M. P., Nombela, C. \& Sanchez, M. (1995). Molecular basis of cell integrity and morphogenesis in Saccharomyces cerevisiae. Microbiol Rev 59, 345-386.

Costigan, C., Gehrung, S. \& Snyder, M. (1992). A synthetic lethal screen identifies $S L K 1$, a novel protein kinase homolog implicated in yeast cell morphogenesis and cell growth. Mol Cell Biol 12, 1162-1178.

Cross, G. A. M. (1990). Glycolipid anchoring of plasma membrane proteins. Annu Rev Cell Biol 6, 1-39.

Delneri, D., Gardner, D. C., Bruschi, C. V. \& Oliver, S. G. (1999). Disruption of seven hypothetical aryl alcohol dehydrogenase genes from Saccharomyces cerevisiae and construction of a multiple knock-out strain. Yeast 15, 1681-1689.

Dirick, L., Moll, T., Auer, H. \& Nasmyth, K. (1992). A central role for SWI6 in modulating cell cycle START-specific transcription in yeast. Nature 357, 508-513.

Elliott, B. \& Futcher, B. (1993). Stress resistance of yeast cells is largely independent of cell cycle phase. Yeast $\mathbf{9}, 33-42$.

Englund, P. T. (1993). The structure and biosynthesis of glycosyl phosphatidylinositol protein anchors. Annu Rev Biochem 62, 121-138.

Garay-Arroyo, A. \& Covarrubias, A. A. (1999). Three genes whose expression is induced by stress in Saccharomyces cerevisiae. Yeast 15, 879-892.

Gardner, D. C. J., Tomlin, G. C., Cele, T., Hamilton, G. A., James, C. M., Stateva, L. I. \& Oliver, S. G. (1996). Physical mapping of the centromere-proximal region of chromosome IV-L defines the placement of genes USO1, MBP1, PSA1 and SLC1. Yeast 12, 411-413.

Gentzsch, M. \& Tanner, W. (1996). The PMT gene family: protein O-glycosylation in Saccharomyces cerevisiae is vital. EMBO J 15, 5752-5759.

Gentzsch, M. \& Tanner, W. (1997). Protein O-glycosylation in yeast: protein-specific mannosyltransferases. Glycobiology 7, 481-486.

Gimeno, C. J., Ljungdahl, P. O., Styles, C. A. \& Fink, G. R. (1992). Unipolar cell divisions in the yeast $S$. cerevisiae lead to filamentous growth: regulation by starvation and RAS. Cell 68, 1077-1090.

Hashimoto, H., Sakakibara, Y., Yamasaki, M. \& Yoda, K. (1997). Saccharomyces cerevisiae VIG9 encodes GDP-mannose pyrophosphorylase, which is essential for protein glycosylation. J Biol Chem 272, 16308-16314.

Heery, D. M., Cannon, F. \& Powell, R. (1990). A simple method for subcloning DNA fragments from gel slices. Trends Genet 6, 173. Herscovics, A. \& Orlean, P. (1993). Glycoprotein biosynthesis in yeast. FASEB J 7, 540-550.

Hill, J., Ian, K. A., Donald, G. \& Griffiths, D. E. (1991). DMSOenhanced whole cell yeast transformation. Nucleic Acids Res 19, 5791.

Innis, M. A. \& Gelfand, D. H. (1990). Optimization of PCR. In PCR Protocols - A Guide to Methods and Applications, pp. 3-12. Edited by M. A. Innis, D. H. Gelfand, J. J. Sninsky \& T. J. White. San Diego, CA: Academic Press.

Irie, K., Levin, D. E., Levin, K. S., Bakase, M., Araki, H., Matsumoto, K. \& Oshima, Y. (1993). $M K K 1$ and $M K K 2$, which encode Saccharomyces cerevisiae mitogen activated protein kinase kinase homologs, function in the pathway mediated by protein kinase $\mathrm{C}$. Mol Cell Biol 13, 3076-3083.

Ito, H., Fukuda, Y., Murata, K. \& Kimara, A. (1983). Transformation of intact yeast cells treated with alkali cations. $J$ Bacteriol 153, 163-168.

James, C. M., Indge, K. J. \& Oliver, S. G. (1995). DNA sequence analysis of a $35 \mathrm{~kb}$ segment from Saccharomyces cerevisiae chromosome VII reveals 19 open reading frames including RAD54, ACE1/CUP2, PMR1, RCK1, AMS1 and CAL1/CDC43. Yeast 11, 1413-1419. 
Kaiser, C., Michaelis, S. \& Mitchell, A. (1994). Methods in Yeast Genetics. Cold Spring Harbor, NY: Cold Spring Harbor Laboratory.

Klis, F. M. (1994). Cell-wall assembly in yeast. Yeast 10, 851-869. Kobayashi, O., Suda, H., Ohtani, T. \& Sone, H. (1996). Molecular cloning and analysis of the dominant flocculation gene FLO8 from Saccharomyces cerevisiae. Mol Gen Genet 251, 707-715.

Kopecka, M., Gabriel, M., Necas, O., Svoboda, A. \& Venkov, P. V. (1991). Cell surface structures in osmotically fragile mutants of Saccharomyces cerevisiae. J Gen Microbiol 137, 1263-1270.

Kozhina, T., Stateva, L. \& Venkov, P. (1979). Genetic analysis of an osmotic sensitive Saccharomyces cerevisiae mutant. Mol Gen Genet 170, 351-354.

Kukuruzinska, M. A., Bergh, M. L. E. \& Jackson, B. J. (1987). Protein glycosylation in yeast. Annu Rev Biochem 56, 915-944.

Lee, K. S. \& Levin, D. E. (1992). Dominant mutations in a gene encoding a putative protein kinase $(B C K 1)$ bypasses the requirement for Saccharomyces cerevisiae protein kinase C homolog. Mol Cell Biol 12, 172-182.

Lee, K., Irie, K., Gotoh, Y., Watanabe, Y., Araki, H., Nishida, E., Matsumoto, K. \& Levin, D. (1993). A yeast mitogen activated protein kinase homolog (Mpk1p) mediates signalling by protein kinase C. Mol Cell Biol 13, 3067-3075.

Leidich, S. D., Kostova, Z., Latek, R. R., Costello, L. C., Drapp, D. A., Gray, W., Fassler, J. S. \& Orlean, P. (1995). Temperaturesensitive yeast GPI anchoring mutants gpi2 and gpi3 are defective in the synthesis of $\mathrm{N}$-acetylglucosaminyl phosphatidylinositol: cloning of the GPI2 gene. J Biol Chem 270, 13029-13035.

Levin, D. E. \& Bartlett-Heubusch, E. (1992). Mutants in the Saccharomyces cerevisiae PKC1 gene display a cell cycle-specific osmotic stability defect. J Cell Biol 116, 1221-1229.

Lussier, M., Sdicu, A. M., Camirand, A. \& Bussey, H. (1996). Functional characterization of the YUR1, KTR1, and KTR2 genes as members of the yeast KRE2/MNT1 mannosyltransferase gene family. J Biol Chem 271, 11001-11008.

Lussier, M., Sdicu, A. M., Bussereau, F., Jacquet, M. \& Bussey, H. (1997a). The Ktr1p, Ktr3p, and Kre2p/Mnt1p mannosyltransferases participate in the elaboration of yeast $\mathrm{O}$ - and $\mathrm{N}$ linked carbohydrate chains. J Biol Chem 272, 15527-15531.

Lussier, M., Sdicu, A. M., Winnett, E., Vo, D. H., Sheraton, J., Dusterhoft, A., Storms, R. K. \& Bussey, H. (1997b). Completion of the Saccharomyces cerevisiae genome sequence allows identification of KTR5, KTR6 and KTR7 and definition of the ninemembered KRE2/MNT1 mannosyltransferase gene family in this organism. Yeast 13, 267-274.

Lussier, M., White, A. M., Sheraton, J. \& 17 other authors (1997c). Large scale identification of genes involved in cell surface biosynthesis and architecture in Saccharomyces cerevisiae. Genetics 147, 435-450.

Madden, K., Sheu, Y. J., Baetz, K., Andrews, B. \& Snyder, M. (1997). SBF cell cycle regulator as a target of the yeast $P K C$-MAP kinase pathway. Science 275, 1781-1784.

Maerkisch, U., Reuter, G., Stateva, L. I. \& Venkov, P. (1983). Mannan structure analysis of the fragile Saccharomyces cerevisiae mutant VY1160. Int J Biochem 15, 1373-1377.

Marini, N. J., Meldrum, E., Buehrer, B., Hubberstey, A. V., Stone, D. E., Traynor-Kaplan, A. \& Reed, S. I. (1996). A pathway in the yeast cell division cycle linking protein kinase $\mathrm{C}(\mathrm{Pkc1})$ to activation of Cdc28 at START. EMBO J 15, 3040-3052.

Martinez-Pastor, M. T., Marchler, G., Schuller, C., Marchler-Bauer, A., Ruis, H. \& Estruch, F. (1996). The Saccharomyces cerevisiae zinc finger proteins $M s n 2 p$ and $M s n 4 p$ are required for transcriptional induction through the stress response element (STRE). EMBO J 15, 2227-2235.

Matsumoto, K., Uno, I., Toh-e, A., Ishikawa, T. \& Oshima, Y. (1982). Cyclic AMP may not be involved in catabolite repression in Saccharomyces cerevisiae: evidence from mutants capable of utilizing it as an adenosine source. J Bacteriol 150, 277-285.

Mazzoni, C., Zarzov, P., Rambourg, A. \& Mann, C. (1993). The SLT2/MPK1 MAP kinase homolog is involved in polarised growth in Saccharomyces cerevisiae. J Cell Biol 123, 1821-1833.

Molina, M., Martin, H., Sanchez, M. \& Nombela, C. (1998). MAP kinase-mediated signal transduction pathways. In Yeast Gene Analysis: Methods in Microbiology, vol. 26, pp. 375-393. Edited by A. J. P. Brown \& M. F. Tuite. San Diego, CA: Academic Press.

Mosch, H. U., Kubler, E., Krappmann, S., Fink, G. R. \& Braus, G. H. (1999). Crosstalk between the Ras2p-controlled mitogenactivated protein kinase and cAMP pathways during invasive growth of Saccharomyces cerevisiae. Mol Biol Cell 10, 1325-1335.

Nakayama, K., Feng, Y., Tanaka, A. \& Jigami, Y. (1998). The involvement of mnn4 and mnn6 mutations in mannosylphosphorylation of O-linked oligosaccharide in yeast Saccharomyces cerevisiae. Biochim Biophys Acta 1425, 255-262.

Nikawa, J., Sass, P. \& Wigler, M. (1987). Cloning and characterization of the low-affinity cyclic AMP phosphodiesterase gene of Saccharomyces cerevisiae. Mol Cell Biol 7, 3629-3636.

Norbeck, J. \& Blomberg, A. (2000). The level of cAMP-dependent protein kinase A activity strongly affects osmotolerance and osmo-instigated gene expression changes in Saccharomyces cerevisiae. Yeast 16, 121-137.

Odani, T., Shimma, Y., Tanaka, A. \& Jigami, Y. (1996). Cloning and analysis of the MNN4 gene required for phosphorylation of $\mathrm{N}$ linked oligosaccharides in Saccharomyces cerevisiae. Glycobiology 6, 805-810.

Odani, T., Shimma, Y., Wang, X. H. \& Jigami, Y. (1997). Mannosylphosphate transfer to cell wall mannan is regulated by the transcriptional level of the MNN4 gene in Saccharomyces cerevisiae. FEBS Lett 420, 186-190.

Orlean, P. (1990). Dolichol phosphate mannose synthase is required in vivo for glycosyl phosphatidylinositol membrane anchoring, $\mathrm{O}$-mannosylation, and $\mathrm{N}$-glycosylation of protein in Saccharomyces cerevisiae. Mol Cell Biol 10, 5796-5805.

Orlean, P. (1997). Biogenesis of yeast wall and surface components. In The Molecular Biology of the Yeast Saccharomyces, vol. 3, pp. 229-362. Edited by J. R. Pringle, J. R. Broach \& E. W. Jones. Cold Spring Harbor, NY: Cold Spring Harbor Laboratory.

Orlean, P., Albright, C. \& Robbins, P. W. (1988). Cloning and sequencing of the yeast gene for dolichol phosphate mannose synthase, an essential protein. J Biol Chem 263, 17499-17507.

Pan, X. \& Heitman, J. (1999). Cyclic AMP-dependent protein kinase regulates pseudohyphal differentiation in Saccharomyces cerevisiae. Mol Cell Biol 19, 4874-4887.

Paravicini, G., Cooper, M., Friedli, L., Smith, D. J., Carpenter, J. L., Klig, L. \& Payton, M. A. (1992). The osmotic integrity of the yeast cell requires a functional PKC1 gene product. Mol Cell Biol 12, 4896-4905.

Parry, J. M., Davies, P. J. \& Evans, W. E. (1976). The effects of 'cell age' upon the lethal effects of physical and chemical mutagens in the yeast, Saccharomyces cerevisiae. Mol Gen Genet 146, 27-35.

Philipova, D. (1985). Transformation of fragile mutants of $S$. cerevisiae. PhD thesis, Bulgarian Academy of Science.

Ram, A. F., Wolters, A., Ten Hoopen, R. \& Klis, F. M. (1994). A new 
approach for isolating cell-wall mutants in Saccharomyces cerevisiae by screening for hypersensitivity to calcofluor white. Yeast 10, 1019-1030.

Rose, M. D., Novick, P., Thomas, J. H., Botstein, D. \& Fink, G. (1987). A Saccharomyces cerevisiae genomic plasmid bank based on a centromere-containing shuttle vector. Gene 60, 237-243.

Rupp, S., Summers, E., Lo, H. J., Madhani, H. \& Fink, G. (1999). MAP kinase and cAMP filamentation signaling pathways converge on the unusually large promoter of the yeast FLO11 gene. EMBO J 18, 1257-1269.

Sambrook, J., Fritsch, E. F. \& Maniatis, T. (1989). Molecular Cloning: a Laboratory Manual, 2nd edn. Cold Spring Harbor, NY: Cold Spring Harbor Laboratory.

Sasaki, T., Toh-e, A. \& Kikuchi, Y (2000). Extragenic suppressors that rescue defects in the heat stress response of the budding yeast mutant tom1. Mol Gen Genet 262, 940-948.

Sass, P., Field, J., Nikawa, J., Toda, T. \& Wigler, M. (1986). Cloning and characterisation of the high-affinity cAMP phosphodiesterase of Saccharomyces cerevisiae. Proc Natl Acad Sci USA 83, 9303-9307.

Schmitt, A. P. \& McEntee, K. (1996). Msn2p, a zinc finger DNAbinding protein, is the transcriptional activator of the multistress response in Saccharomyces cerevisiae. Proc Natl Acad Sci USA 93, 5777-5782.

Sherman, F., Fink, G. R. \& Hicks, J. B. (1986). Methods in Yeast Genetics. Cold Spring Harbor, NY: Cold Spring Harbor Laboratory.

Shimma, Y., Nishikawa, A., bin Kassim, B., Eto, A. \& Jigami, Y. (1997). A defect in GTP synthesis affects mannose outer chain elongation in Saccharomyces cerevisiae. Mol Gen Genet 256, 469-480.

Sikorski, R. S. \& Hieter, P. (1989). A system of shuttle vectors and yeast host strains designed for efficient manipulation of DNA in Saccharomyces cerevisiae. Genetics 122, 19-27.

Stateva, L. I., Oliver, S. G., Trueman, L. J. \& Venkov, P. V. (1991). Cloning and characterisation of a gene which determines osmotic stability in Saccharomyces cerevisiae. Mol Cell Biol 11, 4235-4243.

Tanner, W. \& Lehle, L. (1987). Protein glycosylation in yeast. Biochim Biophys Acta 906, 81-99.

Thevelein, J. M. (1994). Signal transduction in yeast. Yeast 10, 1753-1790.

Thevelein, J. M. \& de Winde, J. H. (1999). Novel sensing mechanisms and targets for the cAMP-protein kinase A pathway in the yeast Saccharomyces cerevisiae. Mol Microbiol 33, 904-918.

Toda, T., Cameron, S., Sass, P. \& Wigler, M. (1987a). Three different genes in the yeast Saccharomyces cerevisiae encode the catalytic subunits of the cAMP-dependent protein kinase. Cell 50, 277-287.
Toda, T., Cameron, S., Sass, P., Zoller, M., Scott, J. D., McMullen, B., Hurwitz, M., Krebs, E. G. \& Wigler, M. (1987b). Cloning and characterisation of $B C Y 1$, a locus encoding the regulatory subunit of the cAMP-dependent protein kinase in yeast. Mol Cell Biol 7, 1371-1377.

Tokiwa, G., Tyers, M., Volpe, T. \& Futcher, B. (1994). Inhibition of $\mathrm{G}_{1}$ cyclin activity by the RAS/cAMP pathway in yeast. Nature 371, 342-345.

Trevillyan, J. M. \& Pall, M. L. (1979). Control of cAMP levels by depolarising agents in fungi. J Bacteriol 138, 397-403.

Varela, J. C., Praekelt, U. M., Meacock, P. A., Planta, R. J. \& Mager, W. H. (1995). The Saccharomyces cerevisiae HSP12 gene is activated by the high-osmolarity glycerol pathway and negatively regulated by protein kinase A. Mol Cell Biol 15, 6232-6245.

Venkov, P. V., Hadjiolov, A. A., Battaner, E. \& Schlessinger, D. (1974). Saccharomyces cerevisiae sorbitol dependent fragile mutants. Biochem Biophys Res Commun 56, 559-604.

Venkov, P. V., Milchev, G. I. \& Hadjiolov, A. A. (1975). Rifampicin susceptibility of ribonucleic acid synthesis in a fragile Saccharomyces cerevisiae mutant. Antimicrob Agents Chemother $8,627-632$.

Waltschewa, L. W., Venkov, P. V., Stoyanova, B. B. \& Hadjiolov, A. A. (1976). Degradation of ribosomal precursor and polyadenylic acid-containing ribonucleic acids in Saccharomyces cerevisiae caused by actinomycin D. Arch Biochem Biophys 176, 630-637.

Wang, X. H., Nakayama, K., Shimma, Y., Tanaka, A. \& Jigami, Y (1997). MNN6, a member of the KRE2/MNT1 family, is the gene for mannosylphosphate transfer in Saccharomyces cerevisiae. J Biol Chem 272, 18117-18124.

Ward, A. C. (1990). Single step purification of shuttle vectors from yeast for high frequency back transformation into Escherichia coli. Nucleic Acids Res 18, 5319.

Werner-Washburne, M., Braun, E., Johnston, G. C. \& Singer, R. A. (1993). Stationary phase in the yeast Saccharomyces cerevisiae. Microbiol Rev 57, 383-401.

Wilson, R. B. \& Tatchell, K. (1988). SRA5 encodes the low $K_{\mathrm{m}}$ cyclic AMP phosphodiesterase of Saccharomyces cerevisiae. Mol Cell Biol 8, 505-510.

Yanisch-Perron, C., Vieira, J. \& Messing, J. (1985). Improved M13 phage cloning vectors and host strains: nucleotide sequence of the M13mp18 and pUC19 vectors. Gene 33, 103-119.

Yip, C. L., Welch, S. K., Klebl, F., Gilbert, T., Seidel, P., Grant, F. J., O'Hara, P. J. \& MacKay, V. L. (1994). Cloning and analysis of the Saccharomyces cerevisiae MNN9 and MNN1 genes required for complex glycosylation of secreted proteins. Proc Natl Acad Sci USA 91, 2723-2727.

Received 12 April 2000; revised 31 May 2000; accepted 13 June 2000 